\title{
BANATITIC MAGMATIC AND METALLOGENETIC BELT: METALLOGENY OF THE ROMANIAN CARPATHIANS SEGMENT
}

\author{
ŞERBAN-NICOLAE VLAD ${ }^{1} \&$ TUDOR BERZA ${ }^{2}$
}

ABSTRACT. The Romanian Carpathians sector of the Late Cretaceous Banatitic Magmatic and Metallogenetic belt (BMMB) contains 1) plutons and volcano-plutonic complexes, i. e. calc-alkaline, I-type granitoids, with related ores; 2) shoshonitic plutons that lack economic interest. Two provinces have been delineated: the Apuseni Mts. Province in the North and the Western South Carpathians in the South.

Apuseni Mts. Province is a non-porphyry environment related to more evolved (granodioritic-granitic) magmatism. It is subdivided into three zones: Vlădeasa ( $\mathrm{Pb}-\mathrm{Zn}$ ores of restricted metallogenetic potential); Gilău-Bihor (Fe, Bi, Mo, Cu, W, Au, Ni, Co, Pb, $\mathrm{Zn}, \mathrm{Ag}, \mathrm{U}, \mathrm{B}$ ores / conspicuous peri-batholitic arrangement) and South Apuseni (only one minor Fe-skarn occurrence).

Western South Carpathians Province occurs in Romania and extends in Eastern Serbia. It is subdivided into South Banat Mts.-Timok Zone (SBTZ) and Poiana Ruscă Mts.- North Banat Mts.- Ridanj-Krepoljin Zone (PR-NB-RKZ). SBTZ is a typical porphyry environment of high metallogenetic potential $(\mathrm{Cu}, \mathrm{Au}, \mathrm{Pb}, \mathrm{Zn})$, while PRNB-RKZ is a non-porphyry environment with small to medium size $\mathrm{Pb}, \mathrm{Zn}, \mathrm{Fe}, \mathrm{Cu}$ deposits/prospects exhibiting commonly a peri-plutonic zoning.

The metallogenetic model of the Romanian Carpathians segment of BMMB is conceived based on correlating magma composition/level of emplacement and ore types.

Keywords: BMMB, Romanian Carpathians, metallogenetic units, metallogenetic model

\section{INTRODUCTION}

The purpose of this paper is to present the metallogenetic units and the metallogenetic model of the Romanian Carpathians segment of the Late Cretaceous Banatitic Magmatic and Metallogenic Belt (BMMB).

BMMB (Berza et al., 1998) is a geological environment that belongs to the Alpine-Himalayan Orogen, as a part of a sub-global size magmatic-metallogenetic unit, i.e. Tethyan-Eurasian Metallogenetic Belt (Jankovic, 1977; Jankovic and Petrascheck 1987; Jankovic, 1997). This magmatic-metallogenetic association stems from von Cotta (1864). He named Late Cretaceous intrusions in Banat and Timok as "banatites".

The history of magmatic-metallogenetic correlation involving Late Cretaceous products/banatites throughout the Carpatians and Balkans began a few decades ago. It seems likely that Cioflica and Vlad (1973) initiated this kind of investigation (Fig. 1A). The present authors are involved in recent correlation attempts, e.g. Berza et al. (1998), Vlad (1998).

\footnotetext{
1 "Babeş-Bolyai" University, Department of Mineralogy, 1 M. Kogălniceanu street 3400 Cluj-Napoca, Romania, e-mail: vlad@bioge.ubbcluj.ro

${ }^{2}$ Geological Institute of Romania, 1 Caransebeş street, Bucharest, Romania, e-mail: berza@xnet.ro
} 


\section{CHARACTERISTICS OF BMMB}

BMMB runs from the Apuseni Mts. in the North to the Western South Carpathians, then bends eastward to Srednogorie down to the Black Sea (Fig. 2). It is a somehow discontinuous, L-shaped body as a result of Tertiary clockwise rotation (Fig. 3).

The Banatitic magmatism (Berza et al, 1998) is represented by plutons and/or volcano-plutonic complexes and related dikes. The compositional trends are tholeiitic, calc-alkaline, calc-alkaline high-K to shoshonitic, and peralkaline restricted to Srednogore. Credible isotopic ages reviewed by Berza (2003), i.e. U-Pb zircon, $\mathrm{Re}-\mathrm{O}$ s molybdenite, $\mathrm{Ar}^{40} / \mathrm{Ar}^{39}$, cluster between 87 and $72 \mathrm{My}$ (SantonianCampanian).

Calc-alkaline hydrated magmas are common for Banatitic plutons and most productive from metallogenetic point of view. They are I-type/magnetite series granitoids. The source is deep crustal or upper mantle, as $\mathrm{Sr}^{87} / S^{86} \mathrm{r}$ ratios indicate unimportant upper crust contamination. The evolution lines consist of a more primitive trend $-\mathrm{m} \delta, \delta \rightarrow \gamma \delta$ and a complementary more evolved trend $-\gamma \delta \rightarrow \gamma$.

The Banatitic metallogeny comprises four major types:

- skarn/replacement (Apuseni Mts., Timok, Banat Mts., Ridanj-Krepoljin, Central Srednogore);

- porphyry (South Banat Mts., Timok, Central and Eastern Srednogore);

- massive sulfide (Timok, Central Srednogore);

- vein/stockwork (Eastern Srednogore, North Apuseni Mts., Timok). Co, Ni, B.

Main commodities are $\mathrm{Cu}, \mathrm{Au}, \mathrm{Mo}, \mathrm{Pb}, \mathrm{Zn}, \mathrm{Fe}$, subordinately $\mathrm{Bi}, \mathrm{U}, \mathrm{Ti}$,

Plate Tectonic interpretation suggested that both compressional and extensional settings may be responsible for magmatism and ore formation. Especially Serbian and Bulgarian geologists favoured the eastward subduction associated with closure of the Vardar ocean. Westward subduction stemming from Mure $i$ and Severin oceans is popular among Romanian authors. In both cases transversal and/or along arc zoning (Apuseni Mts. + South Carpathians versus Srednogore) is called upon as evidence for compressional settingrelated genesis. As alternative, genesis related to post-subduction/collisional setting has been promoted by various geologists, such as Popov $(1981,1996)$ or Berza et al. (1998).

Recent careful evaluation of Late Cretaceous igneous rocks beyond BMMB (Berza, 2003) suggest a significant extension of this petrometallogenetic event (Fig. 4). Besides the continuation across the Black Sea into the Pontides, exposures and drilling information show northward extension in the East and West Carpathians and westward extension in the Pannonian Basin. Furthermore, the transverse distribution of the Banatitic Belt upon Eocretaceous structures, 


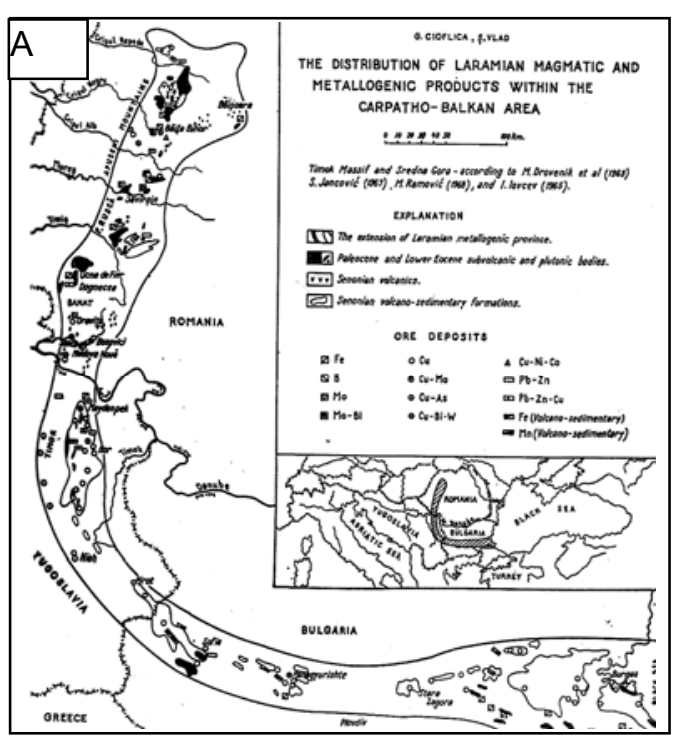

Fig. 1. Early and recent images of $B M M B$. A. according to Cioflica \& Vlad (1973). B. according to Berza et al. (1998).

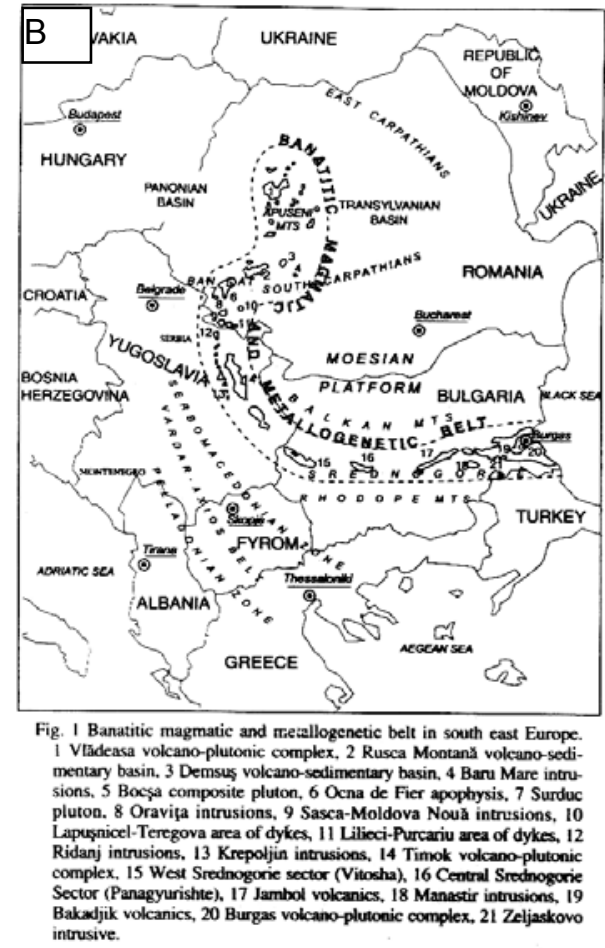

intrusive.

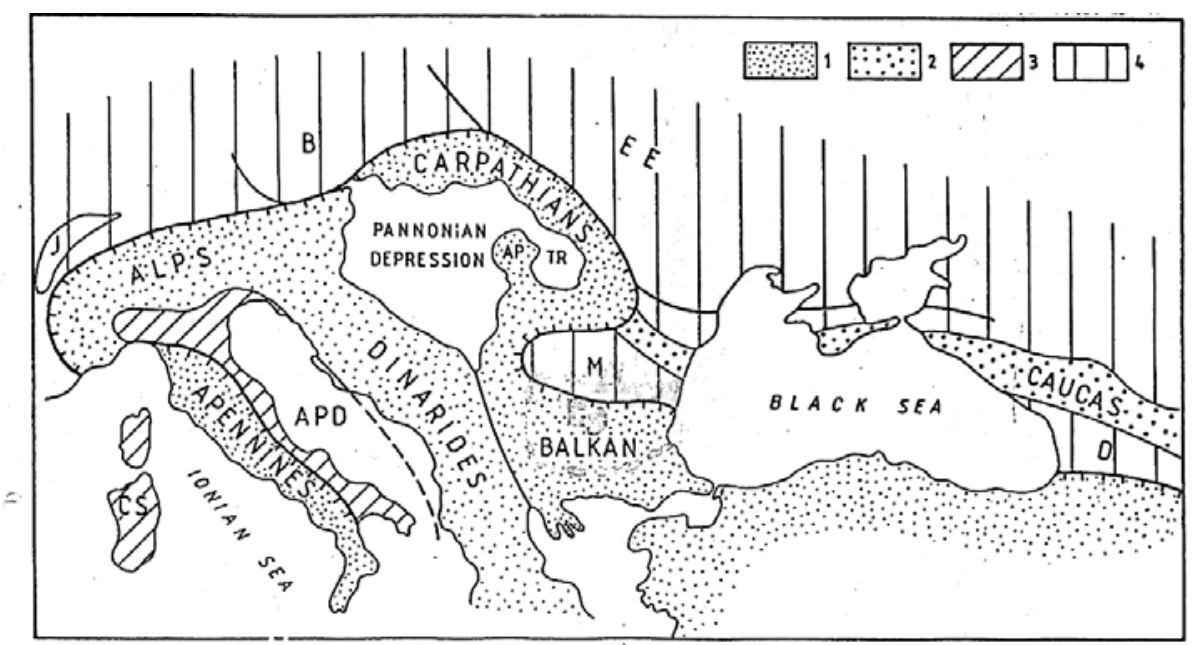

1igend:1-Alpine Mediterranean Belt; 2-Intracratonic Alpine Dobrogea-Crimea-Caucasus Belt; 3-Sialic blocks of the southern continental border; 4-Foreland. AP-Apuseni Mountains; TR - Transylvanian Depression; CSCorso-Sarde block; APD-Apulo-Adriatic block; M-Mocsian block; D-Dziruli block; EE-East European Platform; B-Bohemian Massif; J-Jura Mountains

Fig. 2. BMMB in the South East Europe. 


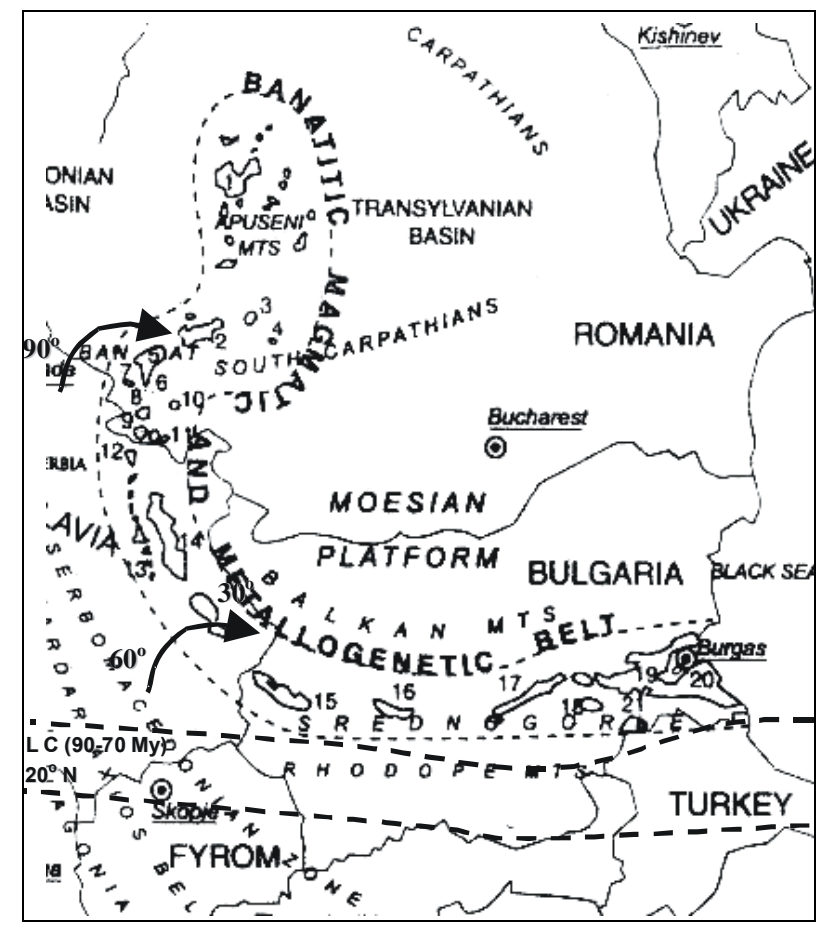

Fig. 3. BMMB location prior to the Tertiary rotation.

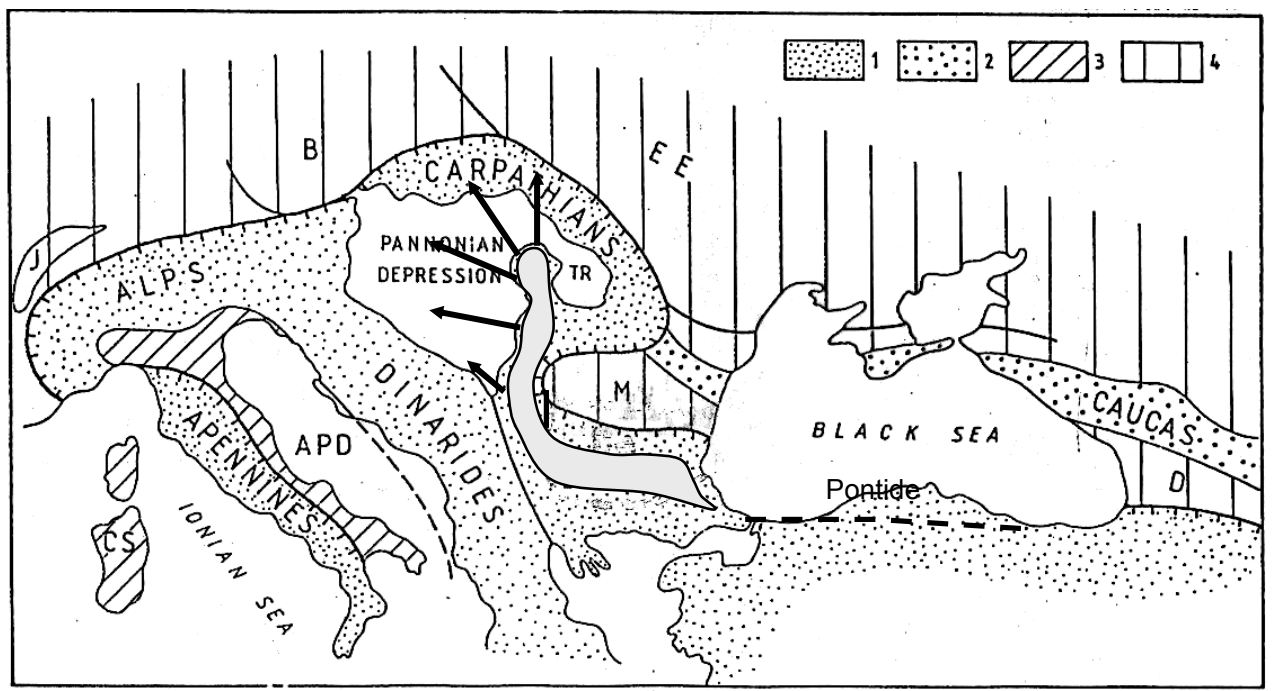

Ligend:1 -Alpine Mediterranean Belt; 2-Intracratonic Alpine Dobrogea-Crimca-Caucasus Belt; 3-Sialic blocks of the southern continental border; $4-$ Foreland. AP-Apuseni Mountains; TR - Transylvanian Depression; CSCorso-Sarde block; APD-Apulo-Adriatic block; M-Mocsian block; D-Dziruli block; EE-East European Platform; B-Bohemian Massif; J-Jura Mountains

Fig. 4. BMMB extension beyond present setting. 
as well as the intimate association of Late Cretaceous extensional basins/Gosau type with coeval igneous rocks argue for a dramatical change of the "classic image" of BMMB and challenge the existent geodynamic models. Nevertheless such evidence can hardly confirm the responsibility of subduction stricto-sensu to magma and ore forming processes.

\section{BMMB IN THE CARPATHIANS}

The most complex occurrences of the BMMB are found in the Carpathian sector (e.g. Jankovic, 1997; Karamata et al., 1997; Vlad, 1998; Berza et al., 1998; Kozelj \& Jelenkovic, 2001).

The magmatism exhibits two trends: plutons and volcano-plutonic edifices with associated ores belong to calc-alkaline I-type granitoids whereas shoshonitic plutons are depleted of economic importance.

The ore typology consists of: porphyry coppers (Au, Mo); Fe, base metal, rare metal skarns; exo-greisen-like Mo stratabound impregnations; epithermal systems - high sulfidation $\mathrm{Cu}-\mathrm{Au}-\mathrm{As} \& \mathrm{~Pb}-\mathrm{Zn}-\mathrm{Cu}-\mathrm{Au}$ massive sulfides and breccia/stockworks with subordinate intermediate to low sulfidation $A u$ veins; high temperature veins (pentametallic formation: $\mathrm{Bi}, \mathrm{U}, \mathrm{Co}, \mathrm{Ni}, \mathrm{Ag}$ ); base metal veins and adjacent replacement bodies; remobilized ores/protores yielding base metal and $U$ veins, $U$ and/or $U$, Cu stratabound lenses, $W, S b$ replacement bodies. Small to medium size deposits prevail.

The Carpathians represent a famous ore-bearing site in terms of European metallogeny due to the following facts:

- various ores have been mined since pre-Roman times;

- skarn deposits such as Ocna de Fier-Dognecea (North Banat Mts.) and Băița Bihorului (North Apuseni Mts.) were described as classic occurrences of this kind since the $19^{\text {th }}$ century;

- the highest grade European U deposit (North Apuseni Mts., exhausted during the fifties) and the largest porphyry copper deposit of Europe (Majdanpek, Timok) are located in the Carpathians.

\section{BMMB IN THE ROMANIAN CARPATHIANS}

Two metallogenetic units of BMMB occur in different structural settings along NE-SW and, respectively N-S major lineation throughout the Romanian Carpathians: Apuseni Mts. Province (AP) and Western South Carpathians Province (WSCP) (Fig. 5).

$\boldsymbol{A P}$ is a non-porphyry environment related to more evolved magmatism $(\gamma \delta \rightarrow \gamma)$. It is subdivided into Vlădeasa Mts. Zone (VZ), Gilău Mts.-Bihor Mts. Zone (GBZ), and South Apuseni Mt. Zone (SAZ) (Fig. 6).

VZ exhibits a restricted metallogenetic potential (mainly $\mathrm{Pb}-\mathrm{Zn}$ ). Base metal veins and /or replacement bodies in volcano-plutonic structures, e.g. Cornițel-Borod, or as remobilisates through the basement, e.g. Scrind-Răchițele, and proximal skarns to replacement bodies, e.g. Pietroasa-Budureasa are to be mentioned. 


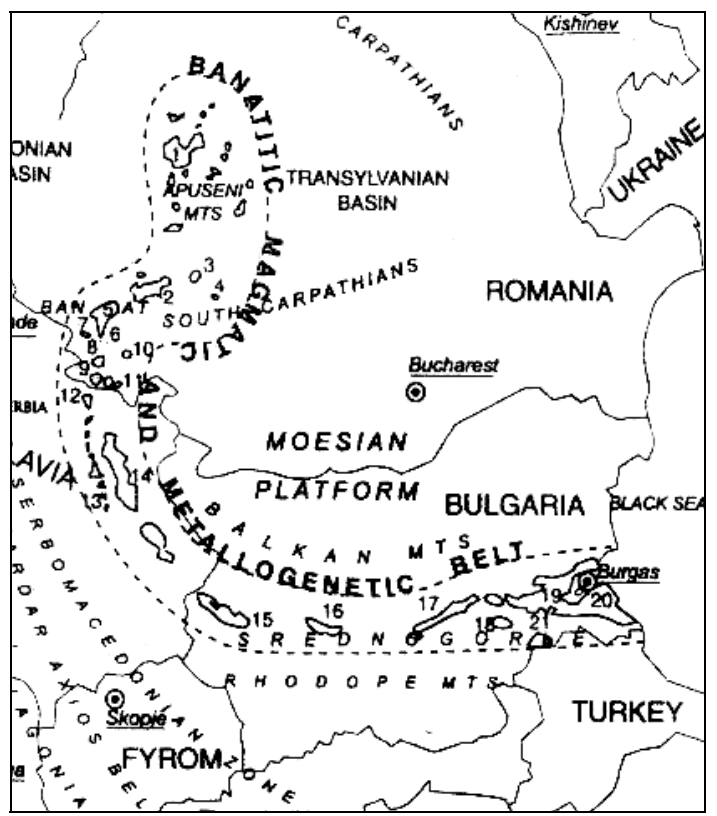

Fig. 5. Metallogenetic units of the Romanian Carpathians segment of BMMB. A. Apuseni Mts. Province; B. Western South Carpathians Province.

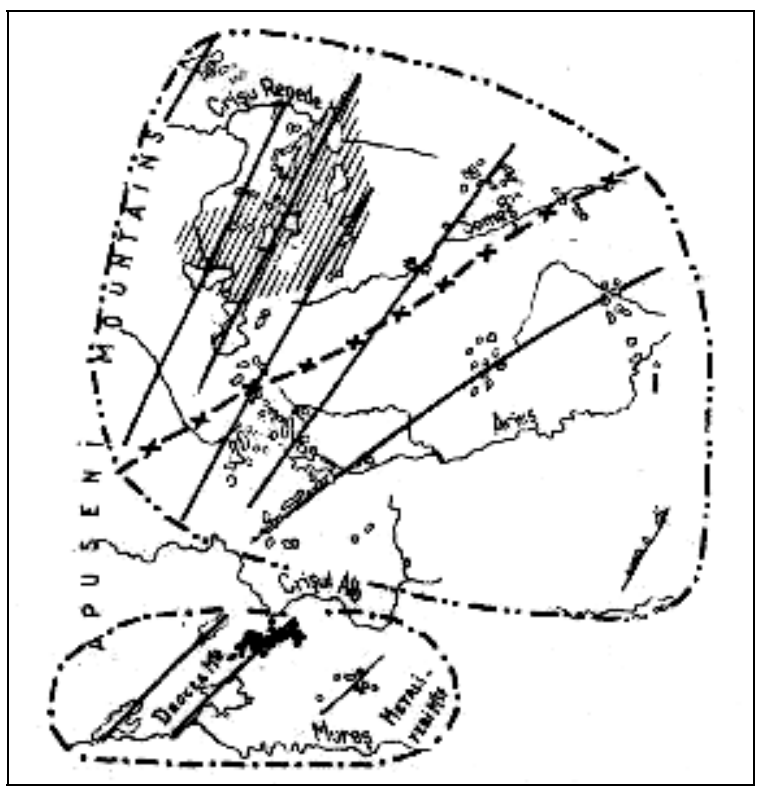

Fig. 6. Apuseni Mts. Metallogenetic Province ( according to Cioflica \& Vlad, 1980, modified). I. Cornitel-Borod: Pb, Zn; II. Vlădeasa: $\mathrm{Pb}, \mathrm{Zn}$; III. Budureasa: $\mathrm{Pb}, \mathrm{Zn}$; IV. Pietroasa: $\mathrm{Pb}, \mathrm{Zn}, \mathrm{B}$; V. Bihor: Mo, Bi, W, Cu, U, Pb, Zn, Co, Ni, Ag, B; VI. Gilău: Pb, Zn; VII. Băişoara: Fe, B; VIII. Trascău; IX. Măgureaua Vaței: Fe. 
GBZ is the most productive unit of the AP. The metallogenesis is complex, i.e. $\mathrm{Fe}, \mathrm{Bi}, \mathrm{Mo}, \mathrm{Cu}, \mathrm{W}, \mathrm{Au}, \mathrm{Ni}, \mathrm{Co}, \mathrm{Pb}, \mathrm{Zn}, \mathrm{Ag}, \mathrm{U}, \mathrm{B}$. Mineralized skarns (both proximal and distal) prevail, spatially associated with veins, stratabound lenses, exo-greisen-like impregnations throughout the famous Băița Bihorului district. $\mathrm{U} \pm \mathrm{Co}, \mathrm{Ni}$ remobilization products are characteristic of this setting too. A conspicuous peri-batholitic arrangement is found around the deep-seated Băița-Dedeş granite intrusion.

SAZ lacks economic importance. Minor Fe skarns occur at Măgureaua Vaței. Other banatitic occurrences are barren. Anyway, SAZ is an area of significant metallogenetic inheritance due to spatial superposition of Jurassic-Eocretaceous, Late Cretaceous and Tertiary igneous assemblages and related ores.

WSCP is subdivided into two zones of contrasting characteristics, that is South Banat Mts.-Timok Zone (SBTZ) and Poiana Ruscă Mts.-North Banat Mts.Ridanj-Krepoljin Zone (PRNBRKZ) (Fig. 7).

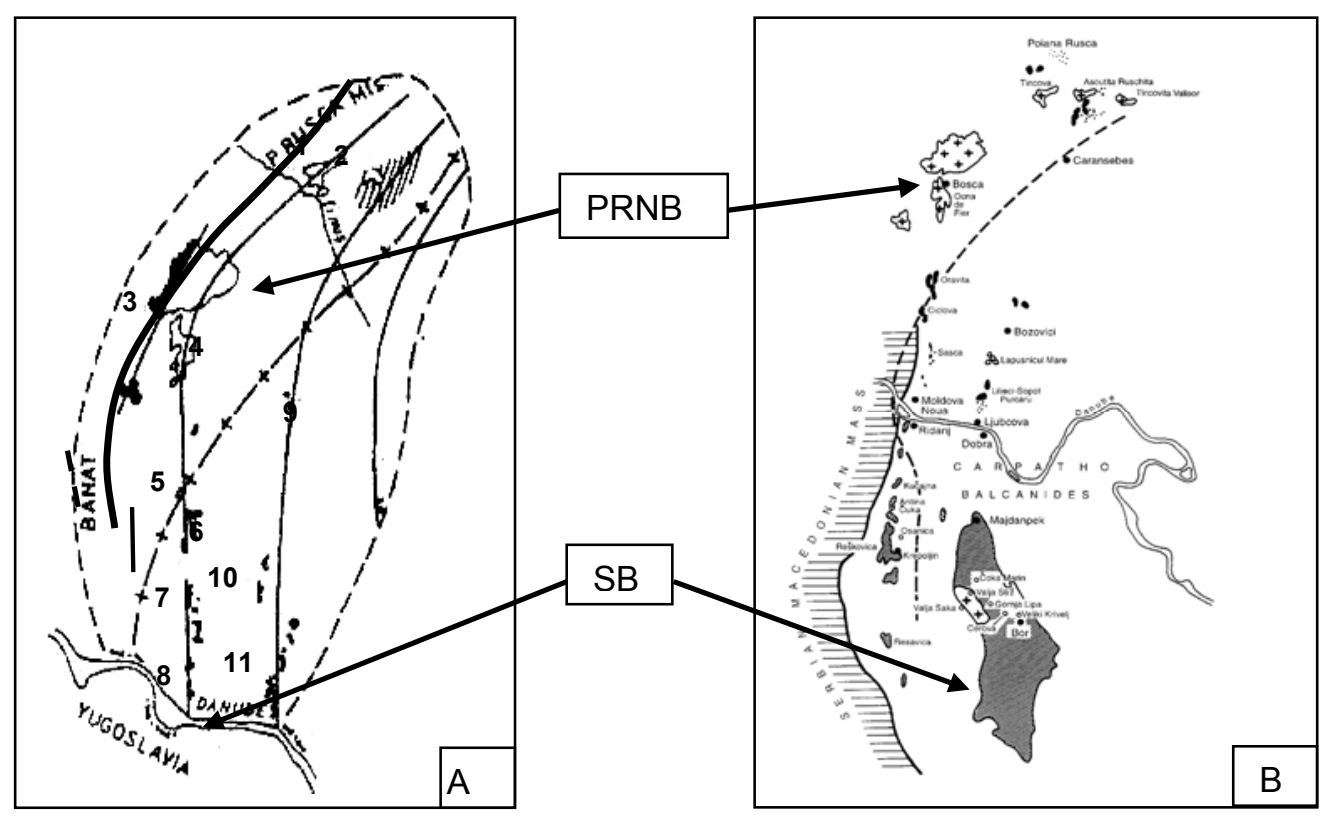

Fig. 7. Western South Carpathians Metallogenetic Province.

A. Distribution of banatitic igneous rocks and ores north of the Danube (according to Vlad, 1979, modified):

1.Tincova-Nadrag: Fe, Pb, Zn; 2. Ascutita-Ruschita: Fe, Pb, Zn: 3. Surduc-West Bocşa;

4. East Bocsa-Ocna de Fier-Dognecea: Fe, Cu, Pb, Zn; 5. Maidan-Oravița: Mo, W, Au;

6. Ciclova: $\mathrm{Cu}, \mathrm{Mo}, \mathrm{W}, \mathrm{Co}, \mathrm{Au}$; 7. Sasca: $\mathrm{Cu}, \mathrm{Mo}$; 8. Moldova Nouă: $\mathrm{Cu}, \mathrm{Mo}$; 9. Văliug: $\mathrm{Au}$;

10. Lapuşnicul Mare: $\mathrm{Cu}, \mathrm{Mo}$; 11. Sopot: $\mathrm{Cu}, \mathrm{Mo}$; 12. Teregova- Lapuşnicel: $\mathrm{Cu}$.

B. Extension of the WSCP south of the Danube ( according to Karamata et al., 1997) 
SBTZ exhibits a Cu character in a typical porphyry environment. The magmatism of of more primitive trend $(\mathrm{m} \delta, \delta \rightarrow \gamma \delta)$ is of high metallogenetic potential:

- especially $\mathrm{Cu}$, but also $\mathrm{Au}, \mathrm{Mo}, \mathrm{Pb}, \mathrm{Zn}$ ores are widespread throughout the Timok volcano-plutonic complex (porphyry deposits in spatial association with epithermal deposits). The extension north of the Danube is less productive, yielding minor porphyry coppers at Lăpuşnicul Mare and Şopot;

- $\mathrm{Cu}(\mathrm{Mo})$ ores in skarn/porphyry deposits ("Arizona type") are related to plutonic apophyses along a major N-S alignment of the South Banat Mts., that is Oravița-Ciclova-Sasca-Moldova Nouă;

- Au remobisation at Văliug (Semenic, South Banat Mts.).

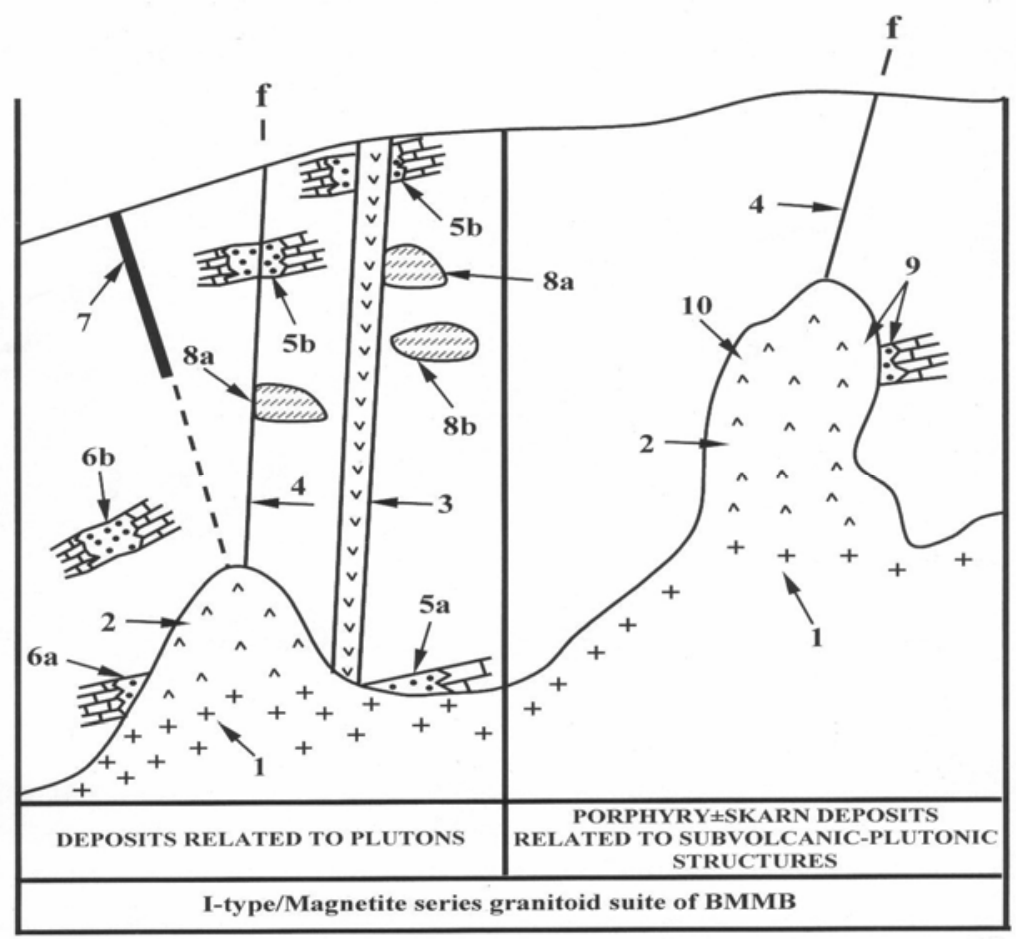

Fig. 8. Metallogenetic model of the Romanian Carpathians segment of BMMB.

1. Pluton; 2. Apophyses; 3. Dyke; 4. Fault; 5. Skarn deposits (Apuseni Mts.): a. proximal; b. distal (and/or replacement bodies); 6. Skarn deposits (Poiana Ruscă-N Banat Mts.): a. proximal; b.distal; 7. High temperature veins/pentametalic formation (N Apuseni Mts.); 8. Stratabound ores (N Apuseni Mts.): a. massive; b. impregnations; 9. Skarn-porphyry deposits (S Banat Mts); 10. Porphyry-pyrite halo deposits (S Banat Mts.);

A. Non-porphyry environment with granodionitic to granitic magmas, plutonic level, skarn mineralization prevails (Apuseni Mts., Poiana Ruscă-N Banat Mts.);

B. Porphyry environment with monzodioritic-dioritic to granodioritic magmas, subvolcanic-hypabissal level, porphyry Cu (Mo) with skarn or pyrite halo (S Banat Mts.). 
PRNBRKZ is a non-porphyry environment of $\mathrm{Pb}-\mathrm{Zn}$ character. The magmatism is more evolved $(\gamma \delta \rightarrow \delta)$, yielding small to medium size base metal, $\mathrm{Fe}, \mathrm{Cu}$ skarn and/or replacement deposits, e.g. Ruşchita (Poiana Ruscă Mts.), Ocna de Fier-Dognecea (North Banat Mts). The peri-plutonic zoning around Bocşa-Ocna de Fier-Dognecea pluton is to be mentioned.

The metallogenetic model of the Romanian Carpathians segment of BMMB (Fig. 8) was constructed based on:

- correlating magma composition and ore types;

- size of intrusion and level of emplacement;

- geology of intruded rocks;

- timing of fluid separation/porphyry versus non-porphyry environment;

- evolution of ore forming fluids/development of alteration zones.

\section{REFERENCES}

Berza, T. 2003, Late Cretaceous magmatism in South East Europe: extension, duration and origin. GEODE Abstracts Volume, Seggauberg, Austria.

Berza, T., Constantinescu, E., Vlad, S.N. 1998, Upper Cretaceous magmatic series and associated mineralisation in the Carpathian-Balkan Orogen, Resource Geology, Tokyo, 48/4: 281-306.

Cioflica, G., Vlad, S. 1973, The correlation of Laramian metallogenetic events belonging to the Carpatho-Balkan area, Rev. Roum. Geol., 17/2: 207-224.

Cioflica, G., Vlad, S. 1980, Copper sulphide deposits related to Laramian magmatism in Romania, European Copper Deposits, Belgrade, 67-72.

Jankovic, S. 1977, The copper deposits and geotectonic setting of the Tethyan Eurasian metallogenetic belt, Mineralium Deposita 12/1: 37-47.

Jankovic, S. 1997, The Carpatho-Balkanides and adjacent area: a sector of the Tethyan Eurasian metallogenetic belt, Mineralium Deposita 32/5: 426-433.

Jankovic, S., Petrascheck, W.E. 1987, Tectonics and metallogeny of the Alpine-Himalayan belt in the Mediterranean area and western Asia, Episodes 10/3: 169-175.

Karamata, S., Knezevic, V., Pecskay, Z., Djordjevic, M. 1997, Magmatism and metallogeny of the Ridanj-Krepojin belt (eastern Serbia) and their correlation with northern and eastern analogues, Mineralium Deposita 32/5: 452-458.

Kozelj, D.I., Jelenkovic, R.J. 2001, Ore forming environments of epithermal gold mineralization in the Bor metallogenetic zone, Serbia, Yugoslavia, in Mineral Deposits at the beginning of the $21^{\text {st }}$ century, Piestrzywsky et al. (eds.), 2001 Sweets \& Zeitlinger Publ. Lisse, 353-358.

Popov, P. 1981, Magmatectonic features of the Banat-Srednogore belt, Geol. Balcanica 11/2: 43-72. 
ŞERBAN-NICOLAE VLAD, TUDOR BERZA

Popov, P. 1996, Characteristic features of the Banat-Srednogore metallogenic zone, in Plate tectonic aspects of the Alpine metallogeny in the Carpatho-Balkan region, IGCP Project no.356 annual meeting Sofia, 1: 137-154.

von Cotta, B. 1864, Erzlagerstatten in Banat und Serbien, W. Braumuller, Vienna, 105 p.

Vlad, S. 1979, A survey of banatitic (Laramian) metallogeny in the Banat region, Rev. Roum. Geol., 23/1: 39-44.

Vlad, S.N. 1998, Comparative Mesozoic-Cenozoic metallogeny of the Carpathian - Balkan and Southern Cordilleran Orogens, Studia Univ. Babeş-Bolyai, Geologie XLIII/1: 15-41. 